\title{
Tingkat Adopsi Good Agricultural Practices Budidaya Kopi Arabika Gayo oleh Petani di Kabupaten Aceh Tengah
}

\section{Level of Adoption of GAP (Good Agricultural Practices) Gayo Arabica Coffee Cultivation by Farmers in Central Aceh District}

\author{
Mahyuda $^{1}$, Siti Amanah ${ }^{2}$, Prabowo Tjitropranoto ${ }^{2}$ \\ ${ }^{1}$ Universitas Malikussaleh \\ ${ }^{2}$ Departemen Sains Komunikasi dan Pengembangan Masyarakat Fakultas Ekologi Manusia IPB
}

\begin{abstract}
Enhancement of coffee production and quality is carried out through the adoption of the arabica coffee cultivation Good Agricultural Practices (GAP) as recommended by P4S. This study aimed to analyze perceptions of innovation factors and cultivation adoption rates and factors that influence the level of adoption of GAP coffee Arabica coffee cultivation. The study was conducted in Atu Lintang, with 60 farmers as samples according to the recommended GAP cultivation technique. The study was conducted from May to July 2017 by used multiple descriptive and linear regression analysis. The results showed that farmers' assessment of the innovative GAP coffee cultivation characteristics of Gayo arabica included: planting of improved varieties, Gayo cultivation pruning, planting and pruning, making rorak, soil splattering and organic fertilization in Atu Lintang, Aceh Tengah Regency, and this was considered positive. The rate of adoption of high yielding varieties and the manufacture of rorak holes was included in the medium category. Pruning koker, protective planting, soil bursts was included in the high category, while the organic fertilization was in low category. The benefit level of innovation and profit was relatively significantly positive, while the number of family dependents significantly affects the level of adoption GAP coffee cultivation Arabica Gayo in a negative way.
\end{abstract}

Keywords: adoption, Good Agricultural Practices, arabica Gayo, cultivation, farmers

\begin{abstract}
Abstrak
Peningkatan produksi dan mutu kopi melalui penerapan adopsi Good Agricultural Practices (GAP) budidaya kopi arabika sesuai rekomendasi P4S. Tujuan dari penelitian ini adalah menganalisis persepsi terhadap ciri inovasi dan tingkat adopsi budidaya, serta mengidentifikasi faktor-faktor yang mempengaruhi tingkat adopsi GAP budidaya kopi Arabika Gayo. Penelitian dilakukan di Kecamaan Atu Lintang dengan sampel sebesar 60 orang petani yang menerapkan GAP budidaya anjuran. Penelitian dilaksanakan dari bulan Mei-Juli 2017, dianalisis menggunakan analisis deskriptif dan regresi linier berganda. Hasil penelitian menunjukkan penilaian petani tentang ciri inovasi GAP budidaya kopi arabika Gayo anjuran meliputi: penanaman varietas unggul, pemangkasan koker Goyo, penanaman dan pemangkasan pelindung, pembuatan lubang rorak, penggemburan tanah dan pemupukan organik di Kecamatan Atu Lintang Kabupaten Aceh Tengah termasuk positif. Tingkat adopsi penanaman varietas unggul dan pembuatan lubang rorak termasuk pada kategori sedang. Pemangkasan koker, penanaman pelindung, penggemburan tanah termasuk pada kategori tinggi, sedangkan pada pemupukan secara organik berada pada kategori sangat rendah. Tingkat kemanfaatan inovasi dan keuntungan relatif berpengaruh nyata positif, sedangkan jumlah tanggungan keluarga berpengaruh nyata negatif terhadap tingkat adopsi budidaya GAP kopi arabika Gayo.
\end{abstract}

Kata kunci: adopsi Good Agricultural Practices, arabika Gayo, budidaya, petani kopi

\section{Pendahuluan}

Indonesia merupakan salah satu Negara produsen kopi dunia, saat ini Indonesia berada pada urutan ke empat negara pengekspor kopi dunia setelah Brasil, Vietnam, Kolombia dan Negara yang memiliki kopi terbaik di dunia. Dari total produksi yang dihasilkan yakni 639.412 ton, sekitar $67 \%$ kopi untuk kebutuhan ekspor, sedangkan sisanya (33\%) untuk kebutuhan dalam negeri (AEKI, 2015). Produktivitas kopi
Indonesia masih tergolong rendah, yakni sebesar 25-35\% dari potensi bahan tanamnya (DITJENBUN 2014). Secara umum areal tanam dan produksi kopi di Indonesia selama 10 tahun terakhir antara tahun 2002 sampai dengan 2011 tidak mengalami peningkatan, justru mengalami penurunan sebesar 4,6\%, sedangkan permintaan terhadap kopi saat ini, sebesar 2,5\% sampai 3\% (GAEKI 2015). Hal tersebut disebabkan karena pertumbuhan produksi tidak sebanding dengan permintaan, sehingga ratio stock/use terus menurun. 
Selain itu terdapat perubahan persepsi positif terkait manfaat kopi bagi kesehatan (Indonesian Internasional Coffee Symposium: IICS 2014).

Salah satu Kabupaten di Provinsi Aceh sebagai sentral penghasil kopi arabika adalah Kabupaten Aceh Tengah. Kabupaten Aceh Tengah memiliki luas perkebunan kopi rakyat sebesar 48.320 ha dengan jumlah produksi 29.239 ton/tahun (Dinas Kehutanan dan Perkebunan Aceh Tengah 2015). Berbagai upaya telah dilakukan pemerintah Daerah guna meningkatkan produktivitas kopi, terlebih setelah terbitnya Hak Indikasi Geografis (IG) bernomor ID G 000000005 tanggal 28 April 2010. Salah satunya mengusulkan pelepasan kopi arabika sebagai varietas unggul dan pendistribusian bibit tersebut kepada masyarakat (GAEKI, 2015). Upaya tersebut belum cukup, mengingat pertanian berkontribusi besar maka harus selalu berinovasi mengikuti perkembangan dan kebutuhan. Hal ini diperkuat oleh informasi media massa (Antaraaceh. com. 2014 Oktober 14) yang mengutip pernyataan Gubernur Aceh yang menyatakan, “... bukan berarti usaha perkebunan dan bisnis kopi selalu berjalan mulus, tetapi juga mengalami beberapa hambatan misalnya sistem perkebunan dan pengolahan kopi yang belum modernt...".

Karim (2014) menyatakan beberapa faktor yang menyebabkan kualitas citarasa dan produksi kopi arabika dataran Tinggi Gayo berdaya saing rendah, diantaranya karena pemeliharaan belum optimal, kesuburan tanah menurun, sumberdaya manusia kurang, kelembagaan petani lemah, kopi sudah tua, varietas bercampur, pengolahan buah kopi belum seragam dan rantai pemasaran terlalu panjang. Karim juga menambahkan agar memudahkan penanganan permasalahan tersebut perlu dirinci menjadi masalahmasalah yang lebih detil, sehingga program revitalisasi terfokus menghasilkan produktifitas kopi arabika. Menurut Saragih (2013) peningkatan produksi kopi arabika dapat dicapai dengan strategi intensifikasi melalui optimalisasi penggunaan lahan dan tenaga kerja keluarga yang digunakan serta penerapan GAP (Good Agricultural Practices) yang didalamnya terdapat penanaman pohon rindang (naungan) yang sesuai dengan jumlah tanaman utama, pemupukan dengan sistem organik, pemangkasan cabang tidak produktif, konservasi lahan dan pengendalian hama. Penelitian Fatma (2011) tentang analisis fungsi produksi dan efisiensi usahatani kopi rakyat di Aceh Tengah menyatakan bahwa, luas lahan telah melampaui titik efisiensi, sehingga untuk meningkatkan produksi salah satunya dengan peremajaan tanaman dan penggunaan bibit unggul. Senada dengan itu, solusi yang tepat meningkatkan produksi adalah dengan mengubah cara budidaya yang berkembang di masyarakat.

Upaya yang dilakukan petani di Kecamatan Atu Lintang melalui Pusat Pelatihan Pertanian dan Perdesaan Swadaya (P4S) "Maju Bersama" dengan praktik budidaya GAP (Good Agricultural Practices) kopi arabika Gayo, cara ini merupakan modifikasi dari cara-cara lama yang berkembang di masyarakat, diantaranya: penanaman varitas unggul sesuai anjuran, pemangkasan koker (model Gayo), penanaman dan pemangkasan pelindung (naungan), pembuatan lubang rorak, penggemburan tanah dan pemupukan secara organik.

Usaha mengadopsi teknik budidaya kopi arabika Gayo oleh masyarakat setempat belum sepenuhnya diadopsi sesuai anjuran. Adopsi mengandung pengertian yang kompleks dan dinamis, karena pada proses adopsi menyangkut pengambilan keputusan, dimana banyak faktor yang mempengaruhinya, agar dapat memperkirakan sejauh mana suatu teknologi dapat dipahami oleh penggunanya, maka dapat dilihat dari beberapa faktor, diantaranya: karakteristik individu, sifat inovasi, dukungan eksternal (Rogers 2003; Soekartawi 2005). Rogers (2003) menjelaskan untuk dapat memperkirakan sejauh mana suatu inovasi dipahami oleh penggunanya, maka perlu diperhatikan karakteristik dari inovasi tersebut. Suatu inovasi dapat dilihat dari lima ciri inovasi diantaranya: keuntungan relatif (relative advantage), kesesuaian (compatibily), kerumitan (complexity), kemudahan dicoba (triabilitiy) dan kemudahan diamati (observability). Kondisi tersebut merupakan masalah yang harus dipecahkan sehingga kesesuaian adopsi praktik budidaya GAP kopi arabika Gayo anjuran dapat menjadi salah satu alternatif peningkatan produksi dan mutu kualitas.

Berdasarkan latar belakang tersebut tujuan penelitian ini adalah menganalisis penilaian petani terhadap ciri inovasi, menganalisis tingkat adopsi budidaya GAP kopi arabika Gayo dan mengidentifikasi faktor yang berpengaruh terhadap adopsi GAP budidaya kopi arabika Gayo anjuran oleh petani. 


\section{Metode Penelitian}

Penelitian ini menggunakan metode survey dengan analisis statistik deskriptif dan statistik inferensial dianalisis menggunakan regresi linear berganda. Lokasi penelitian di Kecamatan Atu Lintang di Kabupaten Aceh Tengah. Pengumpulan data berlangsung sejak bulan Mei sampai dengan Juli 2017. Populasi 148 orang petani yang menerapkan inovasi GAP budidaya kopi arabika Gayo. Jumlah sampel sebanyak 60 orang. Penentuan jumlah sampel menggunakan rumus Slovin $(\alpha=10$ persen), sampel ditiap-tiap desa dilakukan dengan teknik acak sederhana.

Uji validitas dan uji reliabilitas telah dilakukan pada 30 orang non sampel di Desa Daleng Kabupaten Aceh Tengah. Hasil pengujian diperoleh nilai $\mathrm{r}$ hitung $(0,464$ - 1,000) lebih besar dari nilai $r$ tabel $(0.361)$, dapat disimpulkan seluruh pernyataan dinyatakan valid dan nilai cronbach alpha (0.707 - 0.912), hasil ini menunjukkan bahwa kuisioner pada penelitian reliabel. Data yang dikumpulkan adalah karakteristik internal (X1) meliputi: umur, pendidikan formal, pendidikan, nonformal, pengalaman berusahatani, jumlah tanggungan keluarga, luas lahan, dan tingkat manfaat inovasi $\left(\mathrm{X}_{2}\right)$ faktor eksternal petani meliputi tingkat dukungan penyuluhan, tingkat dukungan pasar, tingkat dukungan informasi, tingkat dukungan tenaga kerja. (X3), Ciri inovasi meliputi: keuntungan relatif, kesesuaian, kerumitan, kemudahan dicoba dan kemudahan diamati. (Y) Tingkat adopsi GAP budidaya kopi arabika Gayo diantaranya: Penanaman varietas kopi arabika Gayo anjuran, pemangkasan koker (model Gayo), penanaman dan pemangkasan pelindung (naungan), pembuatan lubang rorak, penggemburan tanah dan pemupukan organik. Sebelum data di olah menggunakan model regresi, dilakukan transformasi data skala ordinal ke skala interval (Sumardjo 1999).

\section{Hasil dan Pembahasan}

Pusat Pelatihan Pertanian dan Pedesaan Swadaya (P4S) adalah lembaga pelatihan pertanian dan pedesaan yang didirikan, dimiliki, dikelola oleh petani, secara swadaya baik perorangan maupun berkelompok, yang diatur dalam Peraturan Menteri Pertanian Nomor: 03/ Permentan/ PP. 410/ 2010. Berdasarkan pedoman pembinaan kelembagaan dijelaskan bahwa Pusat Pelatihan Petani Perdesaan Swadaya (P4S) mitra bagi penyuluh dalam melaksanakan tugas kepenyuluhan. Pembinaan oleh P4S dimaksudkan sebagai upaya meningkatkan sumberdaya manusia petani dalam bentuk pelatihan/permagangan bagi petani dan masyarakat di wilayahnya.

P4S Maju Bersama sebagai pelopor inovasi praktik GAP budidaya kopi arabika Gayo ini berada di Desa Merah Mege bejarak sekitar $\pm 30 \mathrm{~km}$ dari Ibu kota Kabupaten. Didirikan sejak tahun 2007 yang di inisiasi oleh bapak Zaini ketua KTNA(Kelompok Tani Nelayan Andalan) Aceh. Gagasan awal terbentuknya pusat pelatihan dan pemagangan oleh kelompoktani ini ialah meningkatkan pemahaman, pengelolaan, yang baik mengenai manajemen perkebunan kopi di kalangan kelompok tani. Proses belajar mengajar diterapkan secara langsung dalam bentuk kerja nyata di lapangan sehingga transfer pengetahuan dapat secara tepat dan mudah diadopsi oleh petani. Sistem dan metode belajarnya berdasarkan kebutuhan dan realitas lapangan yang memadukan pengalaman, teori, dan praktek yang dimiliki petani.

\section{Karakteristik Internal Petani}

Hasil analisis karakteristik internal petani (Tabel 1) menunjukkan bahwa sebahagian besar petani responden tergolong dalam usia produktif, dengan variasi umur antara 19 tahun sampai dengan 70 tahun. Hasil penelitian memperlihatkan bahwa lebih dari 70 persen petani responden berusia muda (19-32 tahun) sampai dengan sedang (33-45 tahun). Kondisi ini menunjukkan bahwa secara fisik petani masih kuat dalam menjalankan usahataninya. Menurut Soekartawi (2005) semakin muda usia petani biasanya mempunyai semangat dan rasa ingin tahu yang besar, sehingga lebih cepat melakukan adopsi inovasi. Usia juga dapat dikaitkan dengan pengalaman yang dimiliki. Menurut Nurhardjo (2012) semakin tinggi usia pekerja maka semakin baik pula kinerjanya, karena tingkat keahlian dan keterampilan dipengaruhi oleh pengalaman yang didapat saat berkerja.

Rata-rata pendidikan formal responden setara tamat SMP. Sebagian besar responden menempuh pendidikan setingkat SD dan SMA (kategori rendah dan tinggi). Hal ini karena keterbatasan ekonomi yang dimiliki untuk melanjutkan pendidikan ke jenjang yang lebih tinggi, dan adanya pandangan masyarakat bahwa 
Tabel 1. Sebaran Karakteristik Individu Petani Kopi di Kecamatan Atulintang Kabupaten Aceh Tengah

\begin{tabular}{|c|c|c|c|c|}
\hline No & Karakteristik Individu & Kategori & Jumlah (orang) & $\begin{array}{c}\text { Persentase } \\
(\%)\end{array}$ \\
\hline 1 & $\begin{array}{l}\text { Umur (tahun) } \\
(\text { Rataan }=38,7 \text { tahun }) \\
(\operatorname{Max}=70) \\
(\text { Min=19) }\end{array}$ & $\begin{array}{l}\text { Usia muda (19-32 tahun) } \\
\text { Usia sedang (33-45 tahun) } \\
\text { Usia tua (46-58 tahun) } \\
\text { Usia lanjut ( } \geq 59 \text { tahun) }\end{array}$ & $\begin{array}{r}18 \\
27 \\
12 \\
3\end{array}$ & $\begin{array}{r}30,0 \\
45,0 \\
20,0 \\
5,0\end{array}$ \\
\hline 2 & $\begin{array}{l}\text { Pendidikan formal (tahun) } \\
\text { (Rataan }=9,7 \text { tahun) } \\
(\operatorname{Max}=16) \\
(\operatorname{Min}=6)\end{array}$ & $\begin{array}{l}\text { Sangat rendah }(6 \mathrm{thn} / \mathrm{SD}) \\
\text { Rendah }(9 \text { thn/SMP) } \\
\text { Tinggi ( } 12 \text { thn/SMA) } \\
\text { Sangat tinggi (PT) }\end{array}$ & $\begin{array}{r}26 \\
12 \\
21 \\
1\end{array}$ & $\begin{array}{r}43,3 \\
20,0 \\
35,0 \\
1,6\end{array}$ \\
\hline 3 & $\begin{array}{l}\text { Pendidikan nonformal } \\
(\text { Rataan }=5,55 \text { kali }) \\
(\operatorname{Max}=15) \\
(\operatorname{Min}=0)\end{array}$ & $\begin{array}{l}\text { Rendah ( } \leq 4 \text { kali) } \\
\text { Sedang (5-9 kali) } \\
\text { Tinggi ( } \geq 10 \text { kali) }\end{array}$ & $\begin{array}{r}29 \\
22 \\
9\end{array}$ & $\begin{array}{l}48,3 \\
36,6 \\
15,0\end{array}$ \\
\hline 4 & $\begin{array}{l}\text { Pengalaman berusahatani } \\
(\text { Rataan= } 13,7 \text { tahun }) \\
(\operatorname{Max}=40) \\
(\operatorname{Min}=2)\end{array}$ & $\begin{array}{l}\text { Rendah (2-10 tahun) } \\
\text { Sedang (11-18 tahun) } \\
\text { Tinggi ( } \geq 19 \text { tahun })\end{array}$ & $\begin{array}{r}29 \\
28 \\
3\end{array}$ & $\begin{array}{r}48,3 \\
46,6 \\
5,0\end{array}$ \\
\hline 5 & $\begin{array}{l}\text { Tanggungan keluarga } \\
(\text { Rataan }=4 \text { jiwa/kk) } \\
(\operatorname{Max}=11) \\
(\operatorname{Min}=2)\end{array}$ & $\begin{array}{l}\text { Kecil }(\leq 3 \text { jiwa/kk }) \\
\text { Sedang }(4-6 \text { jiwa/kk) } \\
\text { Besar }(7-9 \text { jiwa/kk) } \\
\text { Sangat besar }(\geq 10 \text { jiwa/kk) }\end{array}$ & $\begin{array}{r}13 \\
37 \\
7 \\
3\end{array}$ & $\begin{array}{r}21,6 \\
61,6 \\
11,6 \\
5,0\end{array}$ \\
\hline 6 & $\begin{array}{l}\text { Luas Lahan } \\
(\text { Rataan } 1.49 \text { ha }) \\
(\text { Max }=4 \text { ha) } \\
(\text { Min }=0,5 \text { ha) }\end{array}$ & $\begin{array}{l}\text { Sempit }(\leq 1,5 \text { ha }) \\
\text { Sedang }(\leq 3 \mathrm{ha}) \\
\text { Luas }(>3 \mathrm{ha})\end{array}$ & $\begin{array}{r}46 \\
11 \\
3\end{array}$ & $\begin{array}{r}76,6 \\
18,3 \\
5,0\end{array}$ \\
\hline 7 & $\begin{array}{l}\text { Tingkat manfaat inovasi } \\
(\mathrm{Max}=100 \\
(\text { Min }=0 \\
(\text { Median }=62.5)\end{array}$ & $\begin{array}{l}\text { Rendah }(0-25) \\
\text { Sedang }(26-50) \\
\text { Tinggi }(51-75) \\
\text { Sangat tinggi }(76-100)\end{array}$ & $\begin{array}{r}13 \\
11 \\
34 \\
2\end{array}$ & $\begin{array}{r}21,6 \\
18,3 \\
56,6 \\
3,3\end{array}$ \\
\hline
\end{tabular}

pendidikan formal tidak terlalu dibutuhkan bila hanya menjadi petani. Rendahnya pendidikan formal yang dimiliki petani menyebabkan pelaksanakan adopsi inovasi relatif lebih lambat karena tingkat kemampuan kognitif dan intelegensi daya pikirnya yang rendah. Hal tersebut sejalan dengan apa yang di sampaikan Suryani et al. (2017) mengatakan bahwa tingkat pendidikan menentukan perilaku seseorang dan mempengaruhi pertimbangan rasional dalam menerima informasi maupun pengambilan keputusan teknologi.

Pada penelitian ini pendidikan nonformal merupakan jumlah keikutsetaan petani mengikuti pelatihan/kursus tani/ sekolah lapang yang berkaitan dengan usahatani budidaya kopi arabika dalam kurun waktu tiga tahun terakhir. Hasil analisis (Tabel 1) menunjukkan bahwa pendidikan nonformal yang diikuti oleh sebahagian besar petani termasuk pada kategori rendah. Ratarata petani hanya mengikuti 5,5 kali pelatihan selama 3 tahun terakhir. Rendahnya pendidikan formal petani karena mayoritas pelatihan hanya diikuti oleh pengurus inti kelompok (ketua, bendahara, sekretaris) dan beberapa petani maju. Disamping itu, program kerja BPP saat ini lebih difokuskan pada tanaman holtikultura dan tanaman jeruk serta pengadaan bantuan sarana produksi (bibit, pupuk, dan mulsa). Semestinya penambahan pengetahuan dapat dilakukan dengan intensitas mengikuti pendidikan nonformal, baik berupa pelatihan, khursus tani sehingga petani bertambah wawasan dan pemahaman bertani. Sebagaimana Herman et al. (2006) menyatakan bahwa pendidikan nonformal seperti program sekolah lapang mempercepat proses perubahan pengetahuan dan pemahaman, dimana petani belajar sekaligus 
memperaktikan pengetahuan tersebut.

Pengalaman akan menjadi dasar pembentukan pandangan yang mengarahkan perhatian seseorang pada minat, dan kebutuhannya berdasarkan pelajaranpelajaran dari masalah karena proses waktu yang dilalui. Hasil penelitian menunjukan bahwa pengalama berusahatani kopi responden cukup bervariasi, mulai dari 2 sampai 40 tahun. Dari keseluruhan petani, mayoritas petani memiliki pengalaman berusahatani rendah (2-10 tahun) dan sedang (11-18 tahun). Pengalaman usahatanikopi dalam kategori rendah yakni kurang dari 11 tahun, karena petani baru berusahatani kopi kembali setelah konflik berkepanjangan di Aceh, sebelumnya mereka exodus ke luar wilayah. Beberapa dari petani yang memiliki pengalaman usahatani rendah merupakan petani berusia muda, yang juga baru menekuni usahatani kopi setelah berumah tangga. Petani dengan pengalaman usahatani lama sebesar 5 persen, berusahatani kopi tersebut merupakan sumber mata pencaharian utama yang diturunkan dari orang tua. Menurut Effendy et al. (2013) semakin lama pengalaman petani semakin luas pengetahuan yang dimiliki dan lebih terbuka terhadap inovasi baru.

Hasil analisis menunjukkan bahwa sebagian besar responden memiliki jumlah tanggungan keluarga kecil (1-3 orang) sampai dengan sedang (4-6 orang) dengan rata-rata jumlah tanggungan keluarga sebanyak 4 orang, terdiri dari kepala keluarga, istri, dan 2 orang anak. Diantara 60 jumlah responden hanya 16 persen petani dengan anggota keluarga besar (7-9 orang) dan sangat besar ( $\geq 10$ orang). Jumlah anggota keluarga petani responden umumnya tidak terlalu besar, cenderung menghasilkan pendapatan tinggi karena biaya yang dikeluarkan untuk kebutuhan sehari-hari petani relatif kecil. Kecilnya jumlah anggota keluarga, memberikan kesempatan petani untuk menerapkan secara intensif inovasi GAP budidaya kopi arabika Gayo. Disamping itu, jumlah tanggungan keluarga merupakan aset modal tenaga kerja, yang dapat difungsikan sebagai tenaga kerja dalam keluarga selama kegiatan usahatani dijalankan. Pada usahatani kopi yang dijalankan, tenaga kerja dari anggota keluarga sangat besar pengaruhnya dalam membantu disetiap kegiatan. Umumnya semua anggota keluarga petani kopi ikut terlibat bersamasama berkerja membantu usahatani. Hal ini senada seperti yang di sampaikan Yulida (2012) jumlah tanggungan keluarga berperan dari segi meningkatkan produktivitas, karena peran serta anggota keluarga yang turut membantu usahatani.

Lahan merupakan salah satu faktor produksi usaha pertanian yang sangat penting dalam pengembangan usaha. Luas lahan berkaitan erat dengan penyediaan sarana produksi, tenaga kerja dan permodalan. Secara teoritis semakin luas lahan garapan maka semakin besar biaya produksi yang dikeluarkan, hal ini terkait juga dengan perencanaan penerapan inovasi GAP budidaya kopi arabika Gayo. Luas lahan yang diusahakan petani kopi di lokasi penelitian cukup bervariasi, antara 0.54 hektar. Tabel 1 menunjukan bahwa mayoritas petani memiliki luasan lahan pada kategori sempit $(0,5-1,5$ ha). Rata-rata petani memiliki lahan seluas 1,49 ha, dengan jumlah tanggungan keluarga kecil dan sedang mengindikasi bahwa petani responden mempunyai potensi sumberdaya lahan cukup memadai untuk mendukung kegiatan usaha, karena kebutuhan hidup yang tidak terlalu besar dan pemanfaatan tenaga kerja keluarga yang dilibatkan dalam mengelola usahatani kopi. Hal senada dengan apa yang disampaikan Sudarko (2012) starategi yang relevan peningkatan produksi kopi dengan mengintensifkan usahatani kopi melalui penerapan inovasi yang sesuai dengan lokalitas setempat, hal ini terkait dengan efisien ekonomi dan optimalisasi dalam penggunaan input produksi usahatani.

Hasil analisis menunjukkan tingkat manfaat inovasi termasuk dalam kategori tinggi (Tabel 1). Rata-rata produksi kopi arabika Gayo sebelum menerapkan inovasi budidaya GAP berkisar antara $0.5-0.8$ ton (biji kering) per musim tanam, dan produksi setelah menerapkan inovasi GAP berkisar antara 0.8 sampai dengan 1.2 ton/ ha. Penerapan GAP budidaya kopi arabika Gayo bagi petani memberikan pengaruh pada peningkatan hasil produksi dan mutu kopi, sehingga memberikan rangsangan kepada petani untuk terus mengembangkan usahataninya. Hal ini didukung oleh penelitian Marios dan Olga (2013) yang menyatakan bahwa faktor yang memotivasi petani mengadopsi sistem pertanian yang berbeda adalah keyakinan mereka dalam menghasilkan produk yang berkualitas dan tambahan penghasilan dari usaha yang dijalankan.

\section{Faktor Eksternal Petani}

Selain karakterisik petani, terdapat beberapa faktor 
eksternal lainnya yang mempengaruhi adopsi inovasi. Faktor eksternal merupakan ciri-ciri yang dapat menekan seseorang yang berasal dari luar. Faktor eksternal pada penelitian ini adalah: (1) tingkat dukungan penyuluhan, (2) tingkat dukungan pasar, (3) tingkat dukungan informasi dan (4) tingkat dukungan tenaga kerja. Hasil analisis tingkat dukungan faktor eksternal disajikan pada Tabel 2.

Hasil analisis menunjukkan tingkat dukungan penyuluh berada pada kategori sedang (Tabel 2). Hal ini mengindikasikan bahwa kegiatan penyuluhan belum berjalan efektif. kegiatan penyuluhan biasa dihadiri oleh pengurus inti kelompoktani, yaitu ketua, sekretaris dan bendahara kelompok. Metode yang sering digunakan penyuluh terhadap transfer pengetahuan melalui materi ruang dalam bentuk ceramah dan diskusi di lokasi Kantor BPP, sedangkan demontrasi dilakukan di lahan petani yang bersedia dijadikan tempat praktik. Upaya adopsi budidaya GAP kopi arabika Gayo harus ditekankan pada pendampingan yang intensif, serta metode yang tepat, sehingga materi dapat dimengerti, diterima dan dilaksanakan oleh petani khalayak sasaran penyuluhan. Menurut Amanah (2006) keberhasilan kegiatan penyuluhan tidak terlepas dari keikutsertaan petani sebagai subjek perubahan, dan penyuluh sebagai pendamping dengan mendesain secara sistematis materi, media, metode penyuluhan berdasarkan kebutuhan. Keberhasilan kegiatan penyuluhan juga tidak terlepas dari peran aktif penyuluh membantu pada setiap kegiatan. Oleh karenanya, menurut Tjitropranoto (2003) penyuluh pertanian dituntut tidak hanya sekedar sebagai penyampai (desiminator) teknologi dan informasi, tetapi lebih kearah sebagai motivator, dinamisator, pendidik, fasilitator dan konsultan bagi petani.

Hasil analisis menunjukkan tingkat dukungan pasar berada pada kategori sedang (Tabel 2). Dukungan pasar dilihat dari ketersediaan tempat menjual dan kemudahan untuk memasarkan hasil panen bagi sebahagian besar petani tidak menjadi kendala, karena petani biasa menjual hasil panennya ke pedagang pengumpul yang ada di desa, namun harga jual yang diterima petani cenderung fluktuatif. Hal senada seperti yang diungkapkan Putri et al. (2013) bahwa akibat struktur pasar oligopsoni yang terbentuk, harga kopi arabika Gayo cenderung di dominasi oleh eksportir sebagai pembeli, perubahan harga yang terjadi tidak mempengaruhi harga kopi di tingkat petani, petani cenderung sebagai penerima harga. Semestinya salah satu yang mendukung penerapan inovasi dapat berjalan baik adalah harga yang diterima petani terhadap produk pertaniannya yang tinggi, dan harga jual yang diterima seharusnya dapat memberikan jaminan kepada petani kopi di Kabupaten Aceh Tengah sehingga para petani

Tabel 2. Tingkat Dukungan Faktor Eksternal terhadap Adopsi GAP Budidaya Kopi Arabika Gayo di Kecamatan Atu Lintang

\begin{tabular}{|c|c|c|c|c|}
\hline No & Faktor Eksternal & Kategori (skor) & $\mathbf{n}$ & Persentase (\%) \\
\hline \multirow[t]{4}{*}{1} & Tingkat dukungan penyuluhan & Rendah (0-25) & 20 & 33,3 \\
\hline & $\operatorname{Min}=0$ & Sedang (26-50) & 26 & 43,3 \\
\hline & $\mathrm{Max}=100$ & Tinggi $(51-75)$ & 3 & 5,0 \\
\hline & Median $=44.4$ & Sangat tinggi (76-100) & 11 & 18,3 \\
\hline \multirow[t]{4}{*}{2} & Tingkat dukungan pasar & Rendah $(0-25)$ & 9 & 15,0 \\
\hline & $\operatorname{Min}=0$ & Sedang (26-50) & 21 & 35,0 \\
\hline & $\operatorname{Max}=100$ & Tinggi $(51-75)$ & 20 & 33,3 \\
\hline & Median $=56.25$ & Sangat tinggi (76-100) & 10 & 16,6 \\
\hline \multirow[t]{4}{*}{3} & Tingkat dukungan informasi & Rendah $(0-25)$ & 20 & 33,3 \\
\hline & $\operatorname{Min}=0$ & Sedang (26-50) & 18 & 30,0 \\
\hline & $\operatorname{Max}=100$ & Tinggi $(51-75)$ & 15 & 25,0 \\
\hline & Median $=50$ & Sangat tinggi (76-100) & 7 & 11,6 \\
\hline \multirow[t]{4}{*}{4} & Tingkat dukungan tenaga kerja & Rendah $(0-25)$ & 30 & 50,0 \\
\hline & $\operatorname{Min}=0$ & Sedang (26-50) & 10 & 16,6 \\
\hline & $\operatorname{Max}=100$ & Tinggi $(51-75)$ & 11 & 18,3 \\
\hline & Median $=30$ & Sangat tinggi (76-100) & 9 & 15,0 \\
\hline
\end{tabular}


tidak perlu khawatir harga jual anjlok disaat panen tiba, dengan harga yang terjamin, petani akan semakin termotivasi mengadopsi inovasi budidaya secara intensif dan mendorong dalam peningkatan produksi. Sebagaimana disampaikan Lailida et al. (2015) bahwa semakin tinggi harga jual yang diterima, maka semakin tinggi motivasi mengusahakan usahatani kopi.

Tingkat dukungan informasi dilihat dari ketersedian sumber informasi, kemudahan mengakses dan intensitas kunjungan belajar petani ke P4S sebagai lahan kopi percontohan. Hasil analisis menunjukkan tingkat dukungan informasi termasuk dalam kategori rendah (Tabel 2). Rendahnya tingkat dukungan informasi ini dikarenakan ketua P4S sekaligus pelopor inovasi lebih banyak melakukan pembinaan kepada kelompok-kelompok tani di luar daerah. Menurut Rasak dan Amusat (2012) ketersediaan sumber relevan memudahkan petani mengakses informasi yang berkaitan dengan usahataninya. Kecepatan suatu inovasi juga dipengaruhi sumber informasi yang tersedia, sedangkan untuk ke kemudahan mengakses petani hanya perlu menempuh sekitar $\pm 8 \mathrm{~km}$ untuk mengakses informasi bagi desa yang terjauh dengan lokasi P4S dan $\pm 6 \mathrm{~km}$ ke Kantor BPP Kecamatan. Ketersedian informasi sebagai pusat belajar masyarakat, sangat dibutuhkan oleh petani untuk menambah pengetahuan dan keterampilan petani dalam berusahatani. Hal ini di dukung oleh penelitian
Burhansyah (2014) bahwa percepatan adopsi inovasi sangat dipengaruhi secara nyata oleh jarak pemukiman lokasi usahatani, dan jarak pemukiman ke sumber informasi.

Tingkat dukungan tenaga kerja termasuk dalam kategori rendah (Tabel 2). Rendahnya tingkat dukungan tenaga kerja karena pada kegiatan usahatani budidaya kopi, kebutuhan tenaga kerja mayoritas berasal dari anggota keluarga yang terlibat membantu usaha. Kegiatan usahatani kopi yang dilakukan masyarakat jarang menggunakan tambahan tenaga kerja dari luar keluarga. Pada bidang-bidang tertentu yang membutuhkan tambahan tenaga kerja, petani menyikapi kebutuhan tambahan tenaga kerja dengan membangun kelompok kerja secara gotong royong saling membantu dalam kegiatan usahatani. Hal tersebut sejalan dengan hasil penelitian Nuryanti dan Swastika (2011) peran kelompok sangat besar pengaruhnya terhadap percepatan adopsi teknologi melalui forum belajar dan wahana berkerjasama serta unit produksi usahatani.

\section{Ciri Inovasi Budidaya GAP Kopi Arabika Gayo}

Ciri inovasi budidaya GAP kopi arabika Gayo anjuran meliputi: keuntungan relatif, kesesuaian, kerumitan, kemudahan dicoba dan kemudahan diamati. Hasil analisis penilaian petani terhadap ciri inovasi

Tabel 3. Hasil Analisis Penilaian Petani terhadap Ciri Inovasi Budidaya GAP Kopi Arabika Gayo Anjuran di Kecamatan Atu Lintang

\begin{tabular}{|c|c|c|c|c|c|c|c|c|}
\hline \multirow[b]{2}{*}{ No } & \multirow[b]{2}{*}{ Sub Peubah } & \multicolumn{5}{|c|}{ Ciri inovasi } & \multirow[b]{2}{*}{$\begin{array}{l}\text { Total } \\
\text { Skor }\end{array}$} & \multirow[b]{2}{*}{ Kategori } \\
\hline & & 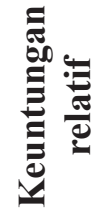 & 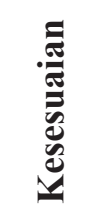 & & 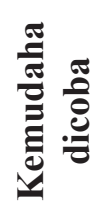 & 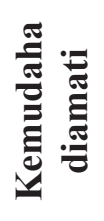 & & \\
\hline 1 & Varietas unggul anjuran & 80,0 & 58,3 & 62,2 & 67,7 & 71,1 & 67,88 & Sedang \\
\hline 2 & Pemangkasan koker & 76,1 & 79,4 & 66,1 & 73,8 & 80,0 & 75,11 & Sedang \\
\hline 3 & Penanaman dan Pemangkasan pelindung & 71,1 & 72,7 & 56,1 & 72,7 & 74,7 & 69,44 & Sedang \\
\hline 4 & Pembuatan lubang Rorak & 68,3 & 68,3 & 60,0 & 63,3 & 69,4 & 65,88 & Sedang \\
\hline 5 & Penggemburan tanah & 61,1 & 69,4 & 67,2 & 60,5 & 65,5 & 64,77 & Sedang \\
\hline 6 & Pemupukan organik & 55,0 & 58,8 & 58,8 & 54,4 & 61,1 & 57,66 & Sedang \\
\hline
\end{tabular}

Keterangan: Skor (0 - 25): Sangat rendah Skor (51 - 75): Sedang
Skor (26 - 50): Rendah

Skor (76 - 100): Tinggi 
budidaya GAP kopi arabika Gayo anjuran disajikan pada Tabel 3.

Penilaian petani tentang varietas unggul anjuran berada pada kategori sedang (Tabel 3). Petani menilai bahwa menerapkan varietas unggul menguntungkan. Hasil wawancara bersama petani varietas anjuran menghasilkan buah yang besar, varietas ini tahan terhadap penyakit karat daun dan hama penggerek batang kopi. Berdasarkan pengamatan, varietas unggul yang dominan petani tanami adalah varietas arabika Gayo 1 (varietas Timtim). Walaupun pada dasarnya terdapat dua jenis varietas unggul anjuran, namun untuk varietas Gayo 2 (varietas borbon) kurang diminati petani dengan lahan berada pada ketinggian 1200-1300 mdpl. Sebagaimana penelitian Salima et al. (2012) bahwa produksi dan mutu fisik biji tertinggi kopi Arabika Gayo 2 diperoleh pada ketinggian tempat lebih dari 1.400 mdpl dengan lereng 0-8 \%. Penilaian petani terhadap kesesuaian varietas unggul anjuran bagi petani cukup sesuai, alasan yang dikemukakan petani karena varietas ini dapat dibudidayakan pada ketinggian 1300-1700 mdpl sesuai dengan lokasi masyarakat berusahatani. Petani menilai bahwa varietas unggul tidak rumit dibudidayakan serta dapat diamati perbedaannya dengan varietas lokal lainnya berdasarkan ciri marfologi tanaman, dari daun, batang dan bentuk buah.

Penilaian petani terhadap sistem pemangkasan koker Gayo berada pada kategori sedang (Tabel 3). Petani menilai pemangkasan koker merupakan salah satu teknik budidaya yang berkaitan dengan penyediaan cabang-cabang untuk menghasilkan buah kopi. Sebagaimana yang disampaikan Hulupi et al. (2013) prinsip pada pemangkasan koker Gayo yakni pemangkasan bentuk dan pemangkasan lepas panen bertujuan mempertahankan kerangka tanaman yang diperoleh dari pemangkasan bentuk dengan cara menghilangkan cabang-cabang tidak produktif, dilakukan sebelum masa pembungaan dan setelah selesai pemanenan. Pemangkasan koker bagi petani sesuai dengan kebutuhan dan cara pemangkasan umumnya yang berkembang dimasyarakat, yakni pemangkasan produksi dan pemangkasan lepas panen. Hasil wawancara sistem pemangkasan koker bagi sebahagian petani sedikit rumit dilakukan, karena pada pemangkasan ini membutuhkan ketelitian pemilihan percabangan untuk mengurangi resiko kegagalan berbuah. Teknik pemangkasan koker mudah dicobakan. Pengamatan dari pemangkasan koker Gayo bagi petani baru terlihat pada saat munculnya bunga bakal buah di masa generatif. Berdasarkan pengamatan, pemangkasan produksi dilakukan dengan membuang tunas air, cabang cacing, cabang balik dan cabang liar. Setelah dua sampai dengan tiga bulan, pemangkasan ringan ini akan diulang kembali sehingga terbentuk cabang produksi, sedangkan pada pemangkasan berat atau sering disebut pemangkasan peremajaan berlaku setelah panen, dengan membuang cabang-cabang yang telah pernah berbuah, cabang balik dan cabang kering untuk dikembalikan kepada pembentukan cabang produksi kembali.

Penialaian petani terhadap penanaman dan pemangkasan pohon pelindung berada pada kategori sedang (Tabel 3). Artinya petani merasakan keuntungan dari adanya penanaman pelindung dan pemangkasannya. Tanaman pelindung diyakini sebagai penghasil bahan organik, pengatur intensitas cahaya matahari yang diterima tanaman kopi juga penghasil bahan organik dari banyaknya daun yang dihasilkan. Disamping itu, dengan adanya penaung dapat menekan pertumbuhan gulma, sehingga persaingan tanaman terhadap perebutan unsur hara dapat diminimalisir. Sebagaimana dikemukakan Prawoto (2008) Lamtoro (Leucaena sp.) yang ditanam rapat dengan jarak tanaman antar baris satu meter mampu menghasilkan pupuk hijau yang dapat menambah kesuburan tanah, murah dan tidak mengganggu lingkungan. Berdasarkan wawancara bersama petani, pemilihan pohon pelindung disesuaikan dengan keadaan lingkungan dan jenis penaung yang dapat tumbuh, seperti lamtoro (Leucaena), dadap dan gamal (Gliricidia). Menurut petani penaungan yang berlebihan berdampak kurang baik bagi pertumbuhan tanaman kopi, terlihat dari berkurangnya produksi yang dihasilkan. Sebaliknya apabila tanaman kopi tidak memiliki penaung maka tanaman kopi mudah mengalami pembuahan lebat, yang menyebabkan tanaman kopi mengering dan mati setelah berproduksi, serta kerentanan tanaman kopi terhadap serangan penyakit. Hal senada seperti yang disampaikan Saragih (2013) dampak positif dari tanaman penaung sebagai penyedia unsur hara dari banyaknya kompos yang terbentuk, namun dampak negatif dari penaung tanpa perawatan, produksi akan menurun karena proses pembungaan berkurang dan berpotensi meningkatkan hama dan penyakit. 
Petani menilai bahwa penanaman dan pemangkasan penaung tidak bertentangan dengan teknik budidaya kopi yang berkembang dimasyarakat. Hasil wawancara tingkat kerumitan dirasakan pada pemangkasan penaung, petani harus menggunakan tangga untuk menjangkau batang dan memilih cabang yang akan dipotong. Menurut petani penanaman dan pemangkasan penaung dapat dicobakan. Keteramatan dari fungsi penaung dan pemangkasannya dilihat dari daya tumbuh tanaman kopi di lokasi kebun. Lahan yang kurang penaung tingkat kesuburan tanahnya berbeda dengan lahan yang diberi penaung. Sebagaimana hasil penelitian Sobari et al. (2010) tanaman penaung berfungsi memberikan tambahan sejumlah hara dan mendistribusikan cahaya secara optimal yang mampu meningkatkan persentase pembuahan tanaman kopi. Tanaman penaung yang ditanami tanpa dilakukan pengontrolan dengan pemangkasan, produksi kopi yang dihasilkan rendah. Hal ini karena kurangnya asupan cahaya yang diterima tanaman kopi sebagai proses fotosintesis dan pertumbuhan tanaman kopi lebih besar untuk pertumbuhan vegetatif. Oleh karenanya petani menanam jenis penaung yang dapat tumbuh baik pada daerah tersebut serta memilih pohon pelindung yang minim perawatan, misalnya jenis lamtoro (Leucaena) yang dalam bahasa lokal disebut pete jemen dan pete ilang pocok.

Penilaian petani terhadap pembuatan lubang rorak berada pada kotegori sedang (Tabel 3). Petani merasakan keuntungan relatif dari pembuatan lubang rorak. Menurut petani, lubang yang dibuat disekitar batang tanaman kopi selain sebagai tempat cadangan makanan berfungsi juga sebagai pengatur kelembaban tanah. Menurut Erfandi (2013) pembuatan lubang diantara tanaman berfungsi sebagai resapan air, menampung serasah tanaman dan penghambat aliran permukaan. Lubang rorak oleh masyarakat difungsikan sebagai tempat proses pembentukan bahan organik dari sisa dedaunan, gulma dan kulit cherry kopi, yang berpengaruh baik terhadap tanaman kopi. Pretty et al. (2011) mengemukakan bahwa pengomposan yang terjadi secara alami dari daun, biji kacang-kacangan dan semak-semak yang membusuk untuk membantu memperbaiki Nitrogen dalam tanah, sehingga mengurangi kebutuhan pupuk anorganik pada tanaman. Pembuatan lubang rorak sesuai dengan kebutuhan dan tidak bertentangan dengan teknik pemeliharaan kopi yang berkembang dimasyarakat.
Petani menilai bahwa tingkat kerumitan pelaksanaan pembuatan rolak pada perbaikan lubang-lubang rorak yang mengalami penimbunan tanah akibat hujan. Menurut petani pembuatan lubang rorak dapat dicobakan pada sekala kecil, namun pada sekala besar pengerjaannya membutuhkan tenaga keja tambahan. Adannya kerjasama yang terbentuk dari keterlibatan petani dalam kelompok sangat membantu proses pengerjaan pembuatan lubang rorak baru disekitar tanaman kopi. Keteramatan lubang rorak dapat dilihat dari lubang-lubang galian pada area sekitar tanaman kopi dan keteramatan fungsi lubang rorak oleh petani dilihat dari tingkat kesuburan pertumbuhan tanaman kopi. Apabila tanaman kopi tumbuh subur pembuatan lubang rorak berfungsi dengan baik begitu juga sebaliknya.

Penilaian petani terhadap penggemburan tanah berada pada kategori sedang (Tabel 3). Keuntungan relatif dari kegiatan penggemburan tanah sebagai penunjang peningkatan produksi karena terjadi peremajaan perakaran tanaman kopi dan proses pencampuran humus yang berada di lapisan atas tanah. Romano (2009) menyatakan penggemburan pada awal musim penghujan meningkatkan produksi karena memperbaiki aerasi tanah dan merangsang pertumbuhan mikrobiologi serta menambah unsur hara melalui air hujan. Penggemburan tanah sesuai dengan kebutuhan dan tidak bertentangan dengan teknik pemeliharaan kopi yang berkembang dimasyarakat. Hasil wawancara bersama petani kerumitan penggemburan tanah pada pelaksanaannya, yang harus menunggu musim penghujan. Pelaksanaan pada saat musim kemarau mengakibatkan tanah menjadi kering karena terjadi penguapan air tanah yang berakibat pada matinya tanaman kopi. Oleh karenanya penggemburan baru dilakukan disaat akan musim penghujan. Menurut petani penggemburan tanah mudah dicobakan. Pengerjaannya biasa dikerjakan bersamaan dengan kegiatan pemupukan. Keteramatan hasil dari penggemburan ini dapat dilihat dari pertumbuhan tanaman kopi diperiode berikutnya dengan munculnya tunas dan bakal cabang baru pada tanaman kopi.

Penilaian petani terhadap pemupukan organik tergolong pada kategori sedang (Tabel 3). Hal ini terlihat dari pernyataan penilaian keuntungan relatif ketersediaan sumber bahan baku organik. Menurut petani bahan 
baku organik cukup tersedia terutama pada saat musim panen, bahan baku organik didapatkan dari kulit buah kopi (cherry kopi). Selain itu bahan baku organik didapatkan juga dari hasil pemangkasan penaung dan pembersihan gulma menggunakan mesin pemotong rumput. Bagi petani penggunaan pupuk organik tidak bertentangan dengan teknik budidaya yang berkembang di masyarakat setempat. Kerumitan pupuk organik menurut petani, saat pengangkutan bahan organik cherry merah kopi dari tempat penggilingan ke lokasi kebun. Hal ini yang membuat petani terkadang enggan melakukan pemupukan secra organik, selain itu waktu pembuatannya menjadi kompos yang relatif lama dan efek hasil aplikasi yang terlihat lamban dibanding pupuk anorganik. Sifat lainnya yang diunggulkan dari ketercobaan pemupukan secara organik, pemberiannya dapat dilakukan tanpa mengenal waktu (musim hujan dan musim kemarau) hanya saja saat bahan organik yang masih berupa kulit merah tidak boleh langsung ditumpuk terlalu dekat dengan batang tanaman kopi, karena dapat membuat tanaman kopi mati akibat terjadinya proses reaksi panas yang dihasilkan dari kulit kopi, sehingga pembuatan lubang rorak oleh petani, dibuat tidak terlalu dekat dengan batang tanaman kopi. Menurut petani hasil dari penggunaan pupuk organik dapat diamati, namun reaksinya terlihat lambat terhadap perkembangan tanaman dibandingkan dengan pemberian pupuk anorganik.

\section{Tingkat Adopsi GAP Budidaya Kopi Arabika Gayo}

Hasil analisis sebaran petani kopi menurut tingkat penerapan adopsi GAP budidaya kopi arabika Gayo anjuran P4S dapat dilihat pada Tabel 4.

Tabel 4 menunjukan bahwa tingkat adopsi petani terhadap varietas anjuran pada kategori sedang. Sekitar 55 persen petani sudah menerapkan varietas anjuran pada lahan mereka dengan baik dan sesuai anjuran. Hal ini menunjukkan bahwa sebahagian besar petani di lokasi penelitian sudah mengetahui jenis varietas anjuran dan jarak tanam yang digunakan serta keunggulan dari varietas anjuran. Menurut Sudaryati (2004) berdasarkan efisiensi teknis dan efisiensi alokatif, pengaturan jumlah dan jarak tanam sangatlah penting untuk mendapatkan produksi yang lebih tinggi. Meskipun varietas unggul anjuran adalah varietas Gayo 1 (Timtim) dan varietas Gayo 2 (Borbon), akan tetapi petani juga menanam varietas lokal lain (yang tidak dan belum dilepas) pada satu hamparan lahan seperti varetas Ateng Super, Ateng Jalok, varietas P88 dan beberapa varietas lokal lainnya. Hal ini sesuai seperti yang disampaikan Romano (2009) yang mengungkapkan terdapat lebih dari 12 varietas dengan keragaman lebih dari 100 hasil persilangan di dataran tinggi Gayo, jenis kopi yang digemari masyarakat adalah jenis Ateng Super yang memiliki biji bulat dan besar yang dapat berbuah setelah dua tahun tanam. Penanaman beberapa jenis varietas dalam satu hamparan kebun, bagi petani memberikan keuntungan yang lebih besar dari besarnnya produksi yang dihasilkan, dari pada usahatani kopi dengan pola monokultur. Padahal menurut Karim (2014) salah satu penyebab kualitas citarasa dan produksi kopi arabika dataran Tinggi Gayo berdaya saing rendah varietas yang ditanam bercampur dalam satu hamparan.

Tabel 4. Sebaran Petani Kopi menurut Tingkat Adopsi Budidaya GAP Kopi Arabika Gayo

\begin{tabular}{clcrc}
\hline No & \multicolumn{1}{c}{ Inovasi } & Menerapkan & Skor & Kategori \\
\hline 1 & Varietas unggul & 33 & 55 & Sedang \\
2 & $\begin{array}{l}\text { Pemangkasan } \\
\text { koker }\end{array}$ & 60 & 100 & Tinggi \\
3 & $\begin{array}{l}\text { Penanaman dan } \\
\text { pemangkasan } \\
\text { pelindung }\end{array}$ & 45 & 75 & Sedang \\
4 & & & \\
5 & $\begin{array}{l}\text { Pembuatan rorak } \\
\text { Penggemburan } \\
\text { tanah }\end{array}$ & 54 & 56,6 & Sedang \\
6 & $\begin{array}{l}\text { Pemupukan } \\
\text { organik }\end{array}$ & 12 & 20 & Tinggi \\
\hline
\end{tabular}

Keterangan:

Skor $(0-25)$ : Sangat rendah

Skor (26 - 50): Rendah

Skor (51 - 75): Sedang

Skor (76 - 100): Tinggi

Tingkat adopsi pemangkasan koker berada pada kategori tinggi. Besarnya jumlah petani yang menerapkan pemangkasan koker Gayo (Tabel 4), mengindikasikan bahwa tingkat adopsi petani terhadap sistem pemangkasan koker Gayo sudah sangat baik dilakukan petani. Menurut petani tanpa pemangkasan tanaman kopi produksi yang dihasilkan tidak maksimal. Dilihat dari kemampuan terhadap pemangkasan kopi oleh petani, tidak jarang dari petani menjadi tenaga upahan mengerjakan pemangkasan pada lahan-lahan lain yang membutuhkan jasa pemangkasan kopi. Hal ini didasari dari kemampuan petani yang sudah 
terampil melakukan pemangkasan. Artinya teknik pemangkasan koker sudah diadopsi dengan baik dan penerapannya berhasil ditularkan kepada petani lain. Penyebarluasan inovasi teknik pemangkasan koker ini, melalui interaksi intensif sesama petani pada kegiatan usahatani kopi. Sebagaimana disampaikan Nuryanti dan Swastika (2011) bahwa kelompok peran sebagai upaya mempercepat dan memperkuat adopsi teknologi melalui forum belajar, wahana berkerjasama dan unit produksi usahatani.

Hasil analisis menunjukkan bahwa tingkat adopsi petani terhadap penanaman dan pemangksan pohon pelindung pada kategori sedang (Tabel 4). Mayoritas petani sudah menerapkan penanaman pohon pelindung dengan baik. Hal ini tidak terlepas dari penilaian petani tentang manfaat pohon pelindung yang memberikan perlindungan terhadap tanaman kopi dan sumber bahan organik. Menurut Evizal et al. (2012) Pohon pelindung menentukan produktivitas buah kopi berkaitan dengan peran pohon pelindung sebagai penghasil seresah dari daun yang gugur dan siklus unsur hara dalam agroekosistem tanaman kopi.

Selain itu tanaman penaung yang ditanam bernilai ekonomi terhadap pendapatan rumahtangga. Petani menanam tanaman lainnya sebagai tanaman penaung seperti jeruk, alpukat, kasmak, kulitmanis, pisang yang menghasilkan kayu, kulit serta buah yang dapat dijual, konsumsi dan dimanfaatkan oleh petani sendiri. Hal ini menunjukan bahwa penanaman pohon sudah sangat baik diadopsi petani di lokasi penelitian.

Tingkat adopsi pembuatan rorak berada pada kategori sedang. Lebih dari setengah responden melakukan pembuatan lubang-lubang rorak di area tanaman kopi (Tabel 4). Pembuatan lubang rorak oleh petani lebih difungsikan sebagai tempat pembentukan kompos. Fungsi lubang rorak juga sebagai pengatur kelembaban tanah sekitar tanaman kopi dan pencegahan erosi. Menurut Idjudin (2011) lubang rorak merupakan lubang penampungan atau peresapan air, bertujuan untuk memperbesar peresapan air ke dalam tanah dan menampung tanah yang tererosi. Pengerjaan pembuatan lubang rorak biasa dikerjakan secara gotong-royong sesama petani dengan membentuk kelompok-kelompok kerja secara bergantian. Hal ini menunjukan bahwa inovasi pembuatan rorak sudah cukup baik diadopsi di tingkat petani.
Tingkat adopsi penggemburan tanah berada pada kategori tinggi. Pada kegiatan penggemburan tanah hampir seluruhnya petani responden mengadopsi (Tabel 4). Hasil pengamatan penggemburan tanah dilakukan dengan menggunakan cangkul disekitar batang tanaman kopi. Jarak yang diupayakan serentang kanopi daun. Pada penggemburan tanah tanaman kopi dibersihkan dari gulma dan sisa-sisa daun, caranya dengan mencangkul tanah sekeliling tanaman serentang kanopi daun. Penggemburan tanah dilakukan awal musim hujan dan dikerjakan setelah selesai masa panen. Umumnya petani melakukan penggemburan tanah ini bersamaan dengan proses pemupukan. Menurut Mawardi et al. (2008) olah tanah perlu dilakukan karena tanah dibawah tajuk kopi setelah 2 tahun menjadi padat dan keras, sehingga secara berkala tanah dibawah tajuk perlu digemburkan. Berdasarkan besarnya jumlah petani yang melakukan, mengindikasikan bahwa inovasi penggemburan tanah sudah diadopsi dengan baik oleh petani.

Tingkat adopsi terhadap pemupukan organik berada pada kategori sangat rendah (Tabel 4). Hanya 20 persen dari total petani responden di lokasi penelitian menerapkan pemupukan organik. Petani mengetahui dan memahami fungsi pupuk organik, namun petani tidak yakin terhadap kemampuan pupuk organik tanpa penambahan pupuk kimia. Penyebab lainnya adalah kekawatiran petani terhadap resiko menurunnya produksi yang dihasilkan. Secara umum petani telah mengetahui manfaat dari pemupukan organik, namun pada penerapannya pemupukan scara organik masih belum sepenuhnya diadopsi dengan baik, karena dasar kebiasaan penggunaan pupuk kimia yang telah lama dikerjakan.

Oleh karenanya sangatah dibutuhkan informasi yang berkaitan dengan teknis pemupukan dan pendampingan tentang penerapan pemupukan yang baik dan benar, sehingga pengetahuan petani tentang penerapan pemupukan organik meningkat dan proses adopsi inovasi dapat berjalan dengan baik.

\section{Faktor yang Berpengaruh terhadap Tingkat Adopsi Budidaya GAP Kopi Arabika Gayo}

Hasil uji regresi berganda menunjukkan bahwa ke tiga peubah bebas yakni karakteristik petani, faktor eksternal dan ciri inovasi secara bersama-sama 
(simultan) berpengaruh terhadap tingkat adopsi budidaya GAP kopi arabika Gayo, dengan nilai $\mathrm{R}$ square sebesar 0,618. Artinya keragaman sebahagian besar dapat dijelaskan oleh model sebesar 61,8 persen pengaruh peubah bebas terhadap peubah terikat Y. Sisanya 38.2 persen dijelaskan oleh faktor lain di luar model.

Pengaruh peubah bebas secara sendiri-sendiri (parsial) terhadap peubah terikat menunjukkan bahwa (Tabel 5), tingkat manfaat adopsi inovasi dan keuntungan relatif berpengaruh nyata terhadap tingkat adopsi budidaya GAP kopi arabika Gayo, sedangkan jumlah tanggungan keluarga berpengaruh nyata, namun pengaruhnya negatif terhadap tingkat adopsi budidaya GAP kopi arabika Gayo. Persamaan regresi yang diperoleh dari peubah bebas terhadap tingkat adopsi budidaya GAP kopi arabika Gayo yaitu:

$\mathrm{Y}=54.327-0.293 \mathrm{X}_{1.5}+0.298 \mathrm{X}_{1.7}+0.344 \mathrm{X}_{3.1} \mathrm{R}^{2}=$ 0.618

Hasil penelitian menunjukkan bahwa faktor umur dan pengalaman tidak berpengaruh nyata terhadap tingkat adopsi budidaya GAP kopi arabika Gayo. Umur berhubungan dengan pengalaman, artinya semakin tua usia maka semakin berpengalaman petani terhadap usahatani yang dikelolannya, tingkat pengetahuan yang dimiliki juga semakin bertambah. Petani yang berpangalaman mampu berfikir maju dalam mengembangkan usahataninya dan mencari solusi terhadap berbagai masalah yang dihadapi. Umur petani di lokasi penelitian tergolong muda sampai dengan sedang. Begitu juga dengan pengalaman berusahatani responden sebahagian besar pada kategori rendah dan sedang.

Tingkat pendidikan formal tidak berpengaruh nyata terhadap tingkat adopsi budidaya GAP kopi arabika Gayo. Tingkat pendidikan formal petani mayoritas hanya menempuh pendidikan setingkat SD dan SMA (rendah dan tinggi). Walaupun tingkat pendidikan formal petani pada kategori tersebut, tetapi tingkat adopsi terhadap budidaya GAP kopi arabika Gayo pada komponen pemangkasan koker, penggemburan tanah dan penanaman serta pemangkasan pelindung sudah di adopsi cukup baik oleh sebahagian besar petani. Tingkat pendidikan nonformal tidak berpengaruh nyata

Tabel 5. Hasil Uji Regresi Faktor-Faktor yang Berpengaruh terhadap Tingkat Adopsi Budidaya GAP Kopi Arabika Gayo

\begin{tabular}{|c|c|c|c|c|}
\hline Sub Peubah & $\boldsymbol{\beta}$ & t-hit & t-tabel & Sig \\
\hline \multicolumn{5}{|l|}{ Karakteristik petani } \\
\hline - Umur & 0,283 & 1,770 & 2,01 & 0,084 \\
\hline - Tingkat pendidikan formal & $-0,010$ & $-0,076$ & 2,01 & 0,940 \\
\hline - Tingkat Pendidikan nonformal & 0,026 & 0,239 & 2,01 & 0,812 \\
\hline - Pengalaman berusahatani & $-0,102$ & $-0,624$ & 2,01 & 0,536 \\
\hline - Jumlah tanggungan keluarga & $-0,293^{*}$ & $-2,529$ & 2,01 & 0,015 \\
\hline - Luas lahan & $-0,042$ & $-0,371$ & 2,01 & 0,713 \\
\hline - Tingkat manfaat inovasi & $0,298^{*}$ & 2,448 & 2,01 & 0,019 \\
\hline Faktor eksternal & 0,038 & 0,352 & 2,01 & 0,726 \\
\hline - Tingkat dukungan penyuluhan & $-0,198$ & $-1,473$ & 2,01 & 0,148 \\
\hline - Tingkat dukungan pasar & $-0,125$ & $-1,065$ & 2,01 & 0,293 \\
\hline - Tingkat dukungan informasi & 0,042 & 0,368 & 2,01 & 0,715 \\
\hline \multicolumn{5}{|l|}{ - Tingkat dukungan tenaga kerja } \\
\hline & $0,344^{*}$ & 2,224 & 2,01 & 0,031 \\
\hline Ciri inovasi & $-0,130$ & $-0,986$ & 2,01 & 0,330 \\
\hline - Tingkat keuntungan relatif & $-0,217$ & $-1,443$ & 2,01 & 0,156 \\
\hline - Tingkat kesesuaian & 0,191 & 1,283 & 2,01 & 0,206 \\
\hline - Tingkat kerumitan & $-0,106$ & $-0,948$ & 2,01 & 0,349 \\
\hline - Tingkat kemudahan dicoba & & & & \\
\hline - Tingkat kemudahan diamati & & & & \\
\hline
\end{tabular}

Keterangan: * nyata pada $\alpha<0,05 n=60$ 
terhadap tingkat adopsi budidaya kopi arabika Gayo. Hal ini karena kegiatan yang diadakan penyuluh hanya diikuti oleh pengurus inti kelompok (ketua, bendahara, sekertaris) dan beberapa petani maju mengingat keterbatasan dana yang dimiliki.

Luas lahan tidak berpengaruh nyata terhadap tingkat adopsi GAP budidaya kopi arabika Gayo. Artinya bahwa semakin luas lahan yang diusahakan petani semakin baik tingkat adopsi terhadap usahatani kopi. Mayoritas petani memiliki luasan lahan pada kategori sempit antara 0.5 sampai dengan 1.5 ha. Hal senada seperti yang di ungkapkan Daniel (2002) semakin sempit lahan usaha, semakin tidak efisien usahataninya, kecuali bila kegiatan usahatani dijalankan dengan tertib manajemen serta penggunaan teknologi yang tepat.

Hasil penelitian menunjukkan (Tabel 5) jumlah tanggungan keluarga berpengaruh nyata negatif terhadap tingkat adopsi budidaya GAP kopi. Pengaruh negatif ini mengindikasi semakin sebesar jumlah anggota keluarga semakin rendah tingkat adopsi budidaya GAP kopi arabika Gayo. Jumlah tanggungan keluarga terlalu besar menjadikan pengusahaan usahatani tidak terpokus karena besarnya pengeluaran dalam pemenuhan kebutuhan hidup. Hal senada seperti hasil penelitian Rahman et al. (2011) yang menyatakan jumlah tanggungan keluarga besar kebutuhan hidup juga akan besar, pengaruh yang ditimbulkan pekerjaan tidak terfokus karena besarnya biaya dikeluarkan untuk kebutuhan hidup.

Tingkat manfaat inovasi merupakan salah satu dari dua faktor peubah karakteristik yang berpengaruh nyata terhadap tingkat adopsi budidaya GAP kopi arabika Gayo. Artinya semakin tinggi manfaat inovasi petani semakin besar tingkat adopsi oleh petani. Walaupun berusahatani kopi merupakan usaha keluarga yang diwariskan secara turun-temurun. Motif utama menerapkan inovasi keinginan kuat untuk meningkatkan produksi dan mutu yang dihasilkan sehingga akan berpengaruh terhadap peningkatan pendapatan. Hal senada seperti yang diungkapkan Suryani et al. (2017) bahwa motivasi utama mengelola lahan pekarangan adalah untuk memenuhi kebutuhan pangan keluarga dan menambah pendapatan keluarga.

Tabel 5 menunjukkan bahwa secara keseluruhan faktor eksternal diantarannya: tingkat dukungan penyuluhan, tingkat dukungan pasar, tingkat dukungan informasi dan tingkat dukungan tenaga kerja tidak berpengaruh nyata terhadap tingkat adopsi budidaya GAP kopi arabika Gayo. Tingkat dukungan penyuluhan tidak berpengaruh nyata terhadap tingkat adopsi budidaya GAP kopi arabika Gayo. Hal ini menunjukkan bahwa kegiatan penyuluhan selama ini belum berjalan efektif. Berdasarkan pengamatan dan wawancara bersama petani kegiatan penyuluhan berupa pertemuan di Kantor BPP hanya diikuti oleh pengurus inti kelompok dan beberapa petani aktif, sedangkan kegiatan pendampingan baru dilaksanakan petugas penyuluh saat program yang diusulkan disetujui oleh Dinas Pertanian, dan petugas penyuluh lebih mengutamakan tugas-tugas administrasi di kantor.

Tingkat dukungan pasar tidak berpengaruh nyata terhadap tingkat adopsi budidaya GAP kopi arabika Gayo. Berdasarkan pengamatan di lapangan hal ini disebabkan karena petani lebih banyak menjual hasil panen kopi kepada pedagang pengumpul yang ada di desa. Pedagang pengumpul langsung mendatangi petani saat musim panen tiba. Alasan petani melakukan penjualan hasil produk kepada pedagang pengumpul, karena lebih cepat memperoleh uang dari hasil penjualan kopi dan kadang-kadang petani terikat penjualan disebabkan pinjaman uang kepada pedagang pengumpul. Disatu sisi dengan adannya pengumpul di desa memudahkan petani melakukan penjualan produk pertaniaannya, namun disisi lain petani tidak dapat menentukan harga jual terhadap produk yang dihasilkan.

Tingkat dukungan informasi tidak berpengaruh nyata terhadap tingkat adopsi budidaya GAP kopi arabika Gayo. Ketersediaan sumber informasi dan kemudahan diakses bukan sebuah faktor penentu inovasi dapat diterima apabila intensitas belajar petani ke sumber informasi rendah. Berdasarkan pendapat petani informasi budidaya GAP tersedia di P4S dan mudah untuk diakses, hanya saja petani pelopor inovasi yang sulit ditemui karena saat ini lebih banyak melakukan pembinaan kepada kelompok-kelompok tani di luar daerah.

Tingkat dukungan tenaga kerja tidak berpengaruh nyata terhadap tingkat adopsi GAP kopi arabika Gayo. Hal ini disebabkan karena tenaga kerja petani kopi di desa-desa penelitian tidak tergantung pada ketersediaan 
tenaga kerja yang berasal dari luar, melainkan lebih menggunakan tenaga kerja yang berasal keluarga dan tenaga kerja anggota kelompok secara gotong royong sebagai tambahan tenaga kerja.

Tingkat kesesuaian, kerumitan, kemudahan dicoba dan kemudahan diamati tidak berpengaruh nyata terhadap tingkat adopsi budidaya GAP kopi arabika Gayo. Hal ini karena, pada penerapan usaha budidaya kopi arabika, petani masih mempertahankan pola budidaya lama, dan praktik- praktik budidaya GAP anjuran belum sepenuhnya dikerjakan dengan baik dan benar dan kecendrungan petani lebih memilih komponen budidaya dari GAP yang pekerjaan tidak rumit, ringan dikerjakan tetapi mendapatkan hasil yang tinggi dan menguntungkan.

\section{Kesimpulan}

Penilaian petani tentang ciri inovasi budidaya GAP kopi arabika Gayo anjuran meliputi: penanaman varietas unggul, pemangkasan koker Goyo, penanaman dan pemangkasan pelindung, pembuatan lubang rorak, penggemburan tanah dan pemupukan organik di Kecamatan Atulintang Kabupaten Aceh Tengah termasuk positif.

Tingkat adopsi penanaman varietas unggul dan pembuatan lubang rorak termasuk pada kategori sedang. Pemangkasan koker, penanaman pelindung, penggemburan tanah termasuk pada kategori tinggi, sedangkan pada pemupukan secara organik berada pada kategori sangat rendah.

Tingkat kemanfaatan inovasi dan keuntungan relatif berpengaruh nyata positif, sedangkan jumlah tanggungan keluarga berpengaruh nyata negatif terhadap tingkat adopsi budidaya GAP kopi arabika Gayo

\section{Daftar Pustaka}

[AEKI]. Asosiasi Eksportir Kopi Indonesia. 2015. Industri Kopi Indonesia. [internet]. [diunduh 2015 Maret 01] tesedia pada: http://www.aeki-aice. org/ page/ industri-kopi/ id.

Antaraaceh.com 2014. Kopi Gayo yang Mendunia. Opini. unggah di]

http: //aceh. antaranews.com/ berita/ 20041/ kopigoyo-yang-mendunia [2015 oktober 14 minggu jam 10.58]

Amanah S. 2006. Penyuluh Perikanan. Jurnal Penyuluhan. 2 (4)

BurhansyahR. 2014.Faktor-faktoryangMempengaruhi Adopsi Inovasi Pertanian pada Gapoktan Puap dan Non Puap di Kalimantan Barat (studi kasus:Kabupaten Pontianak dan Landak). Informatika Pertanian. 23 (1): 65-74.

Daniel M. 2002. Pengantar Ekonomi Pertanian. Jakarta (ID): PT Bumi Aksara.

[DITJENBUN]

Kementrian

Pertanian- Derektorat Jendral Perkebunan. 2014. Derektorat tanaman rempah dan penyegar. Prospek kopi dunia masih cerah. [internet]. [diunggah 2014 November 27] tersedia pada: http://ditjenbun.pertanian. go.id.

Dinas Kehutanan dan Perkebunan Propinsi Aceh. 2015. Rekapitulasi Perkembangan Luas Area dan Produksi Komoditas Perkebunan Rakyat Kabupaten Aceh Tengah.

Erfandi D. 2013. Teknik Konservasi Tanah Lahan Kering untuk Mengatasi Degradasi Lahan pada Desa Mojorejo, Lamongan. Jurnal bumi lestari. 13 (1): 91-97

Effendy, Hanani N, Setiawan B, Muhaimin AW. 2013. Effect Characteristics of Farmers on the Level of Technology

Adoption Side-Grafting in Cocoa Farming at Sigi Regency-Indonesia. JAS. 5 (12): 72.doi:10.5539

Evizal R, Tohari, Prijambada ID, Widada J. 2012. Peranan Pohon Pelindung dalam Menentukan Produktivitas Kopi. Jurnal agrotropika 17(1): 19-23

Fatma Z. 2011. Analisis Fungsi Produksi dan Efisiensi Usahatani Kopi Rakyat di Aceh Tengah. [tesis]. Bogor (ID) Sekolah Pasca Sarjana IPB.

[GAEKI]. Gabungan Eksportir Kopi Indonesia. 2015. Area dan Produksi. [internet]. [diunduh 2015 maret 01] tersedia pada: http:// gaeki.or.id/areal-dan-produksi/.

Herman M, Hutagaol P, Surjono H S, Rauf A, Priyarsono D S. 2006. Analisis Faktor- Faktor yang Mempengaruhi Adopsi Teknologi Pengendalian Hama Penggerek B u a h Kakao: Studi Kasus di Sulawesi Barat. Pelita Perkebunan. 22 (3) 222- 236

Hulupi R, Nugroho D, Yusianto. 2013. K e r a g a a $n$ Beberapa Varietas Lokal Kopi Arabika di Dataran 
Tinggi Gayo. Pelita Perkebunan. 29 (2): 69-81

Hulupi R, Martini E. 2013. Pedoman Budi Daya dan Pemeliharaan Tanaman Kopi di Kebun Campur. Bogor (ID): World Agroforestry Centre (ICRAF) Southeast Asia Regional Program.

[IICS]. Indonesian Internasional Coffee Symposium 2014. Banda Aceh. PERHEPI enews. Rubik opini: (hal 2).

Idjudin AA. 2011. Peranan Konservasi Lahan dalam Pengelolaan perkebunan. Jurnal sumberdaya lahan 5 (2)

Karim A. 2014. Pengembangan Ekonomi Lokal melalui Revitalisasi Kebun Kopi Rakyat Dataran Tinggi Gayo. Jurnal Ekonomi dan Pembangunan. 3 (1)

Lailida JA, Sunartomo AF, Hariyati Y. 2015. Motivasi Petani dan Strategi Pengembangan Usahatani Kopi Arabika Rakyat di Kecamatan Sumber Waringin Kabupaten Bondowoso. Berkala Ilmiah Pertanian 1 (1): 1-7.

Marios k, Olga. 2013. Factors Motivating Farmers to Adoption diferent Agri Food Systems: A Case Study of Two Rural Communities in Greece. Rural society. 23 (1): 32-45.

Mawardi S, Hulupi R, Wibawa A, Wiryadiputra S, Yusianto. 2008. Panduan Budidaya dan Pengolahan Kopi Arabika Gayo. (ID): Pusat Penelitian Kopi dan Kakao Indonesia \& Indonesian Coffee and Cocoa Research Institute (ICCRI).

Nurhardjo B. 2012. Karakteristik dan Kinerja Buruh Wanita pada Gudang Tembakau Gmit di Kecamatan Panti Kabupaten Jember. Bisma jurnal bisnis dan Manajemen. 6 (1): 55 - 68.

Nuryanti S, Swastika DKS. 2011. Peran Kelompoktani dalam Penerapan Teknologi Pertanian. Forum Penelitian Agro Ekonomi. 29 (2): 115-128.

Putri MA, Fariyanti A, Kusnadi N. 2013. struktur dan Integrasi Pasar Kopi Arabika Gayo di Kabupaten Aceh Tengah dan Bener Meriah. Bulletin RISTRI. 4(1): 47-54

[PERMENTAN] Peraturan Menteri Pertanian

Nomor: 3/ Permentan/ PP.410/ 1/ 2010. Tentang Pedoman Pembinaan Kelembagaan Pelatihan Pertanian Swadaya.

Prawoto A A. 2008. Hasil kopi dan siklus hara mineral dari pola tanam kopi dengan beberapa spesies tanaman kayu industri. Pelita Perkebunan 224 (1): 1-21.
Pretty J, Toulmin C, Williams S. 2011. Sustainable Intensification in African Agriculture. IJAS 9 (1): 5-24. doi:10.3763.

Rogers E M. 2003. Diffusion of Innovations. Fifth Edition. New York:The Free Press.

Romano. 2009. Kajian Sistem Agribisnis Kopi Organik di Daerah Pegunungan Gayo. Jurnal Aplikasi Manajemen. 7 (1)

Rahman SMA, Haque A, Rahman ASM. 2011. Impact of Fish Farming on Household Income: A Case Study from Mymensingh District. JSS. 7 (2): 127131.

i Rasak OB, Amusat AS. 2012. Perceived Efficacy of Radio Agricultural Commodities Trend Programme Among Farmers in Oyo State, Nigeria. JMCS. 4(3): 46. doi: 10.5897

Saragih JR. 2013. Socioeconomic and Ecological Dimension of Certified and conventional arabica Coffee Production in North Sumatra, Indonesia. AJARD.3 (3): 93-107

Salima R, Karim A, Sugianto. 2012. Evaluasi Kriteria Kesesuaian Lahan Kopi Arabika Gayo 2 di Dataran Tinggi Gayo. Jurnal Manajemen Sumberdaya Lahan. 1 (2): 194-206.

Soekartawi. 2005. Prinsip Dasar Komunikasi Pertanian. Jakarta. (ID): UI-Press.

Sudarko. 2012. Tingkat Kemampuan Anggota Kelompok Tani dalam Penerapan Te k n o l o g i Usahatani Kopi Rakyat. JSEP. 6 (1)

Sudaryati E. 2004. Faktor-faktor yang Mempengaruhi Produksi Kopi Rakyat di Kabupaten Temanggung: Kasus di Kecamatan Candiroto, Kabupaten Temanggung. [tesis]. Semarang (ID) Universitas Diponegoro.

Sumardjo. 1999. Transformasi Model Penyuluh Pertanian Menuju Pengembangan Kemandirian Petani: kasus di Provinsi Jawa Barat. [disertasi]. Bogor (ID) Institut Pertanian Bogor.

Suryani A. Fatchiya A, Susanto D. 2017. Keberlanjutan Penerapan Teknologi Pengelolaan Pekarangan oleh Wanitatani Di Kabupaten Kuningan. Jurnal Penyuluhan. (13) 1

Sobari I, Sakiroh, Purwanto EH. 2012. Pengaruh Jenis Tanaman Penaung terhadap Pertumbuhan dan Persentase Tanaman Berbuah Pada Kopi Arabika Varietas Kartika 1. Buletin RISTRI. 3 (3): 2017-222

Tjitropranoto P. 2003. Penyuluh Pertanian Masakini Dan Masa Depan. dalam: Ida Yustina dan Adjat 
Jurnal Penyuluhan, September 2018 Vol. 14 No. 2

Sudradjat. Membentuk Pola Prilaku Manusia Pembangunan. Bogor. (ID): IPB Press.

Yulida R. 2012. Kontribusi Usahatani Lahan Pekarangan Terhadap Ekonomi Rumah Tangga Petani di Kecamatan Kerinci Kabupaten Pelalawan. IJAE: 3 (2):409 